DEMOGRAPHIC RESEARCH

VOLUME 31, ARTICLE 3, PAGES 71-104

PUBLISHED 3 JULY 2014

http://www.demographic-research.org/Volumes/Vol31/3/

DOI: $10.4054 /$ DemRes.2014.31.3

Research Article

Do co-residence and intentions make a difference? Relationship satisfaction in married, cohabiting, and living apart together couples in four countries

Tsui-o Tai

Janeen Baxter

Belinda Hewitt

This publication is part of the Special Collection on "New Relationships from a Comparative Perspective,” organized by Guest Editors Anne-Rigt Poortman and Belinda Hewitt.

(c) 2014 Tsui-o Tai, Janeen Baxter \& Belinda Hewitt.

This open-access work is published under the terms of the Creative Commons Attribution NonCommercial License 2.0 Germany, which permits use, reproduction \& distribution in any medium for non-commercial purposes, provided the original author(s) and source are given credit.

See http:// creativecommons.org/licenses/by-nc/2.0/de/ 


\section{Table of Contents}

$\begin{array}{lll}1 & \text { Introduction } & 72\end{array}$

$2 \quad$ Background $\quad 73$

$2.1 \quad$ Living apart together relationships 73

2.2 Union type and relationship satisfaction $\quad 75$

$\begin{array}{lll}2.3 & \text { Macro-institutional context } & 77\end{array}$

$3 \quad$ Methods $\quad 79$

$\begin{array}{ll}3.1 & \text { The sample }\end{array}$

3.2 Dependent variable $\quad 81$

$\begin{array}{lll}3.3 & \text { Independent variables } & 81\end{array}$

$\begin{array}{lll}3.3 .1 & \text { Relationship type } & 81\end{array}$

3.3.2 Controls $\quad 82$

$\begin{array}{lll}3.4 & \text { Analytic strategy } & 83\end{array}$

$4 \quad$ Results $\quad 84$

4.1 Descriptive results $\quad 84$

$\begin{array}{lll}4.2 & \text { Regression results } & 86\end{array}$

5 Discussion $\quad 92$

$6 \quad$ Acknowledgments $\quad 95$

$\begin{array}{ll}\text { References } & 96\end{array}$

$\begin{array}{ll}\text { Appendix } & 103\end{array}$ 


\title{
Do co-residence and intentions make a difference? Relationship satisfaction in married, cohabiting, and living apart together couples in four countries
}

\author{
Tsui-o Tai ${ }^{1}$ \\ Janeen Baxter ${ }^{2}$ \\ Belinda Hewitt ${ }^{3}$
}

\begin{abstract}
BACKGROUND

A large body of research has compared relationship satisfaction and quality in cohabiting versus married relationships. Despite increased recognition of couples in living apart together (LAT) relationships, very little research has examined the experiences of couples in LAT relationships compared to co-residential unions.
\end{abstract}

\section{OBJECTIVE}

Our aim is to develop knowledge about the experiences of different union types by investigating relationship satisfaction of people in LAT, cohabiting, and marital relationships. We differentiate those with intentions to marry for cohabiters, and those with intentions to marry or live together in LAT relationships. We also examine differences by gender and country.

\section{METHODS}

Using data from Wave 1 of the Generations and Gender Survey in France, Germany, Australia, and Russia ( $\mathrm{n}=9,604)$, OLS regressions are estimated to investigate a) differences in relationship satisfaction across relationship types, and b) across countries.

\section{RESULTS}

Married people have the highest levels of relationship satisfaction. People in nonmarital unions with intentions to marry or live together are significantly more satisfied than those without marriage or cohabitation intentions. Those in LAT relationships with no intentions to live together have the lowest levels of relationship satisfaction. There is evidence of cross-national variation with differences in relationship satisfaction by

\footnotetext{
${ }^{1}$ University of Queensland, Australia. E-Mail: t.tai@uq.edu.au.

${ }^{2}$ University of Queensland, Australia. E-Mail: j.baxter@uq.edu.au.

${ }^{3}$ University of Queensland, Australia. E-Mail: b.smeaton@uq.edu.au.
} 
union type most pronounced in Australia and Russia. Gender differences are found with women reporting lower levels of relationship satisfaction than men.

\section{CONCLUSIONS}

LAT relationships are qualitatively different to co-residential unions. It is important to further develop our understanding of the experiences of couples in these relationships.

\section{Introduction}

Relationship formation has undergone profound changes in many western nations over the last several decades. The new patterns are characterized by a decline in lifelong marriage and an increasing number and complexity of non-marital relationships. These include de facto cohabitations and non-residential partnerships, such as couples living apart together (LAT), where people identify as being in an intimate relationship but not living with their partner (Duncan and Phillips 2010; Heuveline and Timberlake 2004; Kiernan 2004; Sobotka and Toulemon 2008). These changes highlight the importance of examining variations in relationship experiences and outcomes, such as relationship satisfaction, across union types.

A large and growing body of research is devoted to explaining differences in relationship stability, quality, and satisfaction for de facto cohabiters (henceforth referred to as cohabiters) compared to married couples (Brown 2003; Brown and Kawamura 2010; Liefbroer and Dourleijn 2006). Findings from these studies show higher levels of relationship satisfaction amongst married couples compared to cohabiters, although this varies depending on the marital intentions of cohabiters, with cohabiters intending to marry showing fewer differences in wellbeing compared to married couples (Brown 2003). Less attention has been paid to LAT relationships. Moreover, little research has considered relationship outcome variations amongst different types of LAT relationships, such as those who plan to live together and those who do not. As with cohabiters, relationship intentions of LAT couples are likely to influence relationship satisfaction (Rhoades, Stanley, and Markman 2012).

Much of the research comparing relationship quality and satisfaction between married and cohabiting couples has focused on a single country, particularly the United States (Brown 2003; Smock 2000), but the United States is increasingly shown as an outlier in family patterns and policies (Cherlin 2009; Gornick and Meyers 2009). Moreover, research has documented variations across countries in the degree of institutionalization of non-marital relationships (Kiernan 2001), which has been shown to influence relationship outcomes (Soons and Kalmijn 2009; Wiik, Keizer, and Lappegård 2012). For instance, the Scandinavian countries, where cohabitation is 
virtually indistinguishable from marriage, exhibit fewer differences in relationship satisfaction between marital and cohabiting couples than countries with less normative and institutional support for non-marital unions (Wiik, Keizer, and Lappegård 2012).

In this paper we aim to fill some of the gaps in the literature concerning relationship satisfaction across union type and institutional setting. We use data from the Generations and Gender Survey (GGS) to investigate relationship satisfaction across union type in four countries, Australia, Germany, France and Russia. We chose these countries because they encompass three broad policy regime types: liberal (Australia), conservative (France and Germany) and post-socialist (Russia). This allows an investigation of variations in relationship satisfaction across different institutional contexts because the GGS provides comparable measures across these four countries on key dependent and independent variables. There is already considerable research on LAT couples in the Scandinavian context (Karlsson and Borell 2005; Levin 2004; Levin and Trost 1999) providing insight into relationship quality in social democratic regimes. Our research examines patterns across other regime types.

Our examination extends existing research on relationship satisfaction in several ways. First, we investigate whether relationship satisfaction differs across a wider range of union types than previous research including those in marital, cohabitating and LAT relationships. Second, we investigate the importance of commitment to the relationship by differentiating cohabiters who plan to marry from those who do not, and LAT couples who plan to live together or marry compared to those who do not. Third, we examine gender differences in relationship satisfaction by union type. Fourth, we compare these differences across four countries, Australia, Germany, France and Russia, with varying institutional contexts and differing levels of support for nonmarital unions.

\section{Background}

\subsection{Living apart together relationships}

Following Duncan and Phillips (2010), we define a LAT relationship as an intimate relationship between two people who reside in different households. This is likely to encompass quite a broad range of couples with varying motivations for living apart and at different stages of their life course. It will include couples in the early stages of a dating relationship and potentially on their way to living together, couples who have no intentions to live together, and couples who may have lived together in the past but are now living apart. For the latter two groups, living apart may be a voluntary decision based on a desire for greater independence and freedom, or it may be involuntary and 
Tai, Baxter \& Hewitt: Do co-residence and intentions make a difference?

due to constraints arising from housing availability, employment opportunities in different geographical locations, or family circumstances, such as caring for elderly parents.

For the purposes of the current analyses we do not distinguish among LAT couples in terms of preferences or motivations for living apart together, but we do distinguish, as discussed below, those who intend to marry or live together in the future and those who do not. And we examine variations in relationship satisfaction according to a range of indicators of life course stage such as age, home ownership, relationship duration, previous relationship status, and presence of children. Of course, it should also be noted that other relationship types such as cohabiting and married couples will also encompass a broad range of couples with varying motivations for living together, varying relationship histories and at varying life course stages.

A growing body of research is starting to examine the prevalence, characteristics, and outcomes of couples in LAT relationships. These studies indicate that LAT couples comprise a substantial minority of couple relationships in many western societies. Duncan and Phillips (2010) report that about $10 \%$ of adults in the UK are living in a LAT relationship, with similar figures reported for the US, Australia, and other European countries (Kiernan 2000; Reimondos, Evans, and Gray 2011; Strohm et al. 2010).The proportion of individuals in LAT relationships is high amongst younger age groups, and the never married. But there is also evidence that LAT relationships are relatively common amongst older age groups in some countries, particularly for divorced and widowed people, who may desire an intimate partnership whilst also retaining a high degree of autonomy (Karlsson and Borell 2002). It has also been suggested that LAT unions will become more common over time. Social and demographic forces such as the ageing of the population, increased life expectancy, increasing education and employment opportunities for women potentially leading to greater difficulties for couples to pursue career opportunities in the same geographical location, and high divorce rates may all contribute to a greater prevalence of LAT relationships in the future (Duncan and Phillips 2010; Haskey and Lewis 2006; Levin 2004).

In terms of demographic and attitudinal characteristics, LAT couples have a similar profile to those in other couple relationships. Even when "dating LAT's" are defined similarly to "girlfriend/boyfriend" relationships and "partner LAT's" are defined as more established long-term relationships are differentiated, there are few clearly distinguishable features between LAT couples and other groups (Duncan and Phillips 2010). Some research suggests that LAT couples place less priority on intimate love and sexual relationships than on friendships compared to those in other unions (Roseneil 2006), and hence may be less supportive of traditional partnering relationships. There is also some evidence that LAT couples are less likely to have 
children, more likely to have higher levels of education, and less likely to be religious than cohabiters and married couples (Duncan and Phillips 2010; Reimondos, Evans, and Gray 2011). However, it is likely that these differences may be due to the age and cohort profile of LAT couples compared to other relationship types such as cohabitation or marriage.

\subsection{Union type and relationship satisfaction}

There are a number of reasons why we might expect relationship satisfaction to vary across union type. First, individuals with differing characteristics may be more or less likely to form certain kinds of unions, and these characteristics may, in turn, lead to variations in levels of relationship satisfaction. For example, individuals who hold more traditional views about marriage may be more likely to marry than to cohabit, and may report higher levels of relationship satisfaction than other groups as a result of their beliefs. On the other hand, individuals who are older and previously married with established housing and preferences for staying in their current neighborhood may be more likely to enter LAT relationships than to relocate to a new household in a different setting (Karlsson and Borell 2002). Thus, as discussed below, it is important to control for a range of individual, household, and contextual differences in order to isolate the association between union type and relationship satisfaction.

Alternatively, individuals with varying levels of commitment or attachment to their partner may be more likely to enter certain kinds of relationship than others, and in turn to report varying levels of relationship satisfaction due to differences in levels of attachment. Commitment theory distinguishes between personal dedication to an individual as the reason for the union versus "constraint commitment" (Stanley and Markman 1992). The former type of commitment is the most relevant here and refers to a level of interpersonal commitment that is usually associated with a strong sense of couple identity and a desire for a future together (Stanley, Rhoades, and Markman 2006: 503). This type of commitment may be manifest in a number of ways, including the willingness to put the needs of the relationship above those of the individual (Stanley, Rhoades, and Markman 2006; Stanley, Whitton, and Markman 2004). Couples with lower levels of attachment and commitment to a partner may be less likely to marry than to cohabit or live apart, and in turn report lower levels of relationship satisfaction than those who are married. For example, Wiik, Bernhardt, and Noack (2009) find that Swedish and Norwegian cohabiting couples who intend to get married have similar levels of relationship satisfaction to married couples, and only cohabiting couples with no intention to marry their partner have significantly lower levels of relationship satisfaction. We might expect similar patterns for LAT 
relationships differentiated according to whether they plan to live together or marry in the future. LAT's who plan to live together may be more committed to their relationship, and hence more satisfied, than those who do not plan to live together.

Second, some individuals may be forced into certain kinds of relationships due to circumstances beyond their control and consequently may experience lower levels of relationship satisfaction. For example, couples may have to live apart due to employment opportunities that necessitate different geographical locations at certain stages of a career. Or couples with very low economic resources may be forced to live apart, perhaps in their parental home, because they have insufficient resources to acquire joint housing (Blossfeld and Drobnič 2001). In some cases, a lack of economic resources to afford a wedding ceremony may lead couples to cohabit rather than marry (Manning and Smock 2002). In each of these cases, we expect lower relationship satisfaction for those who are cohabiting or living apart compared to those who are married.

A third reason for variations in relationship satisfaction across relationship types may be the experience of living in a particular kind of relationship. For example, marriage may provide greater levels of relationship satisfaction than other kinds of relationships if it is experienced as secure, long-term and normatively appropriate compared to cohabiting, which may be experienced as more fragile, short-term and less normatively sanctioned. Similarly, living apart together may result in lower levels of relationship satisfaction due to long periods of time apart, particularly for those who would prefer to be living together. On the other hand, if living apart together is motivated by a desire for greater freedom and independence, LAT couples may experience higher levels of relationship satisfaction than those in co-residential relationships.

Further, different types of relationships may provide differential benefits by gender. Much research has shown that men benefit more than women from marital relationships in terms of unpaid domestic and care work, psychological health, and earnings (Bernard 1972; Budig and England 2001; Gupta 1999). In relation to domestic labor and care work, living apart together may provide optimal relationship satisfaction for women who gain emotional and sexual intimacy without the associated burden of domestic work that has been found to accompany the formation of a live-in partnership (Baxter, Hewitt, and Haynes 2008; Gupta 1999). On the other hand, marriage may also provide women with a degree of financial security and access to a larger pool of economic resources, enabling better housing options and economic support during time out of the labor force for child rearing. Even though cohabiting men do more housework than married men, they still do a lot less than cohabiting women (Baxter 2005). Thus, cohabiting women may have lower levels of relationship satisfaction than 
cohabiting men if they experience additional burdens of domestic work without longterm financial security and shared economic resources.

\subsection{Macro-institutional context}

We argue that the macro context is likely to influence both the prevalence of certain kinds of unions as well as subjective outcomes, such as relationship satisfaction, within these union types. Economic security, as a foundation for family formation, has been found to affect union formation individually and at a societal level (Kalmijn 2007). Previous studies show that getting a stable job is positively associated with entry into marriage for both men and women (Oppenheimer, Kalmijn, and Lim 1997; Sweeney 2002) while non-marital partnerships may be a response to economic uncertainty (Huston and Melz 2004). Housing constraints are another obstacle to union formation and childbearing. Housing shortages partially explain the rise in LAT partnerships in Southern European and post socialist countries (Sobotka and Toulemon 2008). As personal and societal economic security facilitates the formation and stability of longterm unions, it is expected that marriage might be further postponed when there is a high level of unemployment or low housing affordability.

Post socialist countries have some of the highest levels of unemployment, job insecurity, and housing deprivation (Nesporova 2002; Norris and Shiels 2007). According to the World Development Indicators database (World Bank 2012), in 2004, the overall unemployment rates in Poland and Slovakia were $18 \%$ and $19 \%$ respectively. Russia and the Czech Republic, on the other hand, had moderate levels of unemployment. In Western European countries, the overall unemployment level was between $4 \%$ and $10 \%$. Australia, the US, and other liberal countries usually have lower unemployment rates. Eastern European countries also experience the severest housing deprivation including poor housing conditions, housing shortages, and drastically increasing housing prices. For instance, in 2008, the ratio of housing price to income was 4.7 in Russia (Michigami 2011). That means that the middle-class household's annual income for almost five years equals the price of a new dwelling.

It is also likely that the subjective experience of relationships vary across the institutional context, partly as a result of variations in relationship prevalence but also in accordance with the degree of normative and legal support for relationship types (Wiik, Keizer, and Lappegård 2012). Differing institutional frameworks provide differing levels of social, economic, and political support for relationships which may influence outcomes in terms of relationship satisfaction. The Nordic states and some Western European countries such as France are characterized by pervasive cohabitation, nonmarital childbearing, high female labor force participation, and relatively egalitarian 
gender attitudes. Other English-speaking countries, including Australia, the US, the UK, and Canada, have intermediate to high levels of cohabitation, out-of-wedlock childbearing, marital dissolution, and female labor force participation (Batalova and Cohen 2002; Chandola, Coleman, and Hiorns 2002; Fuwa and Cohen 2007; Heuveline and Timberlake 2004; World Bank 2012). In these countries where non-marital unions are more prevalent and accepted, it is reasonable to expect that the difference in relationship quality between married couples and those in other unions may be less pronounced.

Post socialist countries, on the other hand, are very diverse. Due to the legacy of communism, female labor force participation tends to be high. However, post socialist countries tend to have relatively conservative attitudes toward cohabitation and gender roles and more traditional divisions of domestic labor. Therefore, non-marital cohabitation, extramarital childbearing, and divorce remain uncommon, although research is indicating increasing trends in these areas in Russia, Estonia, Latvia, and Hungary (Fuwa and Cohen 2007; Gerber and Berman 2009; Sobotka and Toulemon 2008). This suggests that differences in relationship satisfaction across union type in post-socialist countries may be even more pronounced, with those in non-marital unions reporting the lowest levels of satisfaction. On the other hand, given the prevailing lack of acceptance of cohabiting relationships in post-socialist countries, we might also expect that people in LAT relationships could have higher levels of relationship satisfaction because they are not contravening societal norms of living together outside of marriage.

In this paper, we focus on Australia, France, Germany, and Russia. These countries, often grouped in liberal (Australia), conservative (France and Germany), and post socialist country types (Russia), provide divergent social and economic contexts and allow us to observe and compare how structural factors moderate the impact of union types on relationship satisfaction (Deacon 1992; Esping-Andersen 1999; Fajth 1999; Gauthier 2002/3). Table 1 illustrates some characteristics for these countries between 1999 and 2006. In terms of economic development, Russia has the lowest GDP per capita and the least egalitarian income distribution. All countries show high levels of female labor force participation, but a large proportion of women work part time in Australia and Germany compared to the other two countries. France and Germany allocated 29\% of GDP to social spending in 2005 and also provide extensive paid maternity leave and generous family allowances. Australia only recently introduced a paid parental leave scheme in 2011.

Turning to demographic patterns, the crude marriage and divorce rates range from 4.5 to 6.8 and from 2.4 to 4.4 respectively in the four countries. Russia has the highest marriage and divorce rates, whereby cohabitation is common in both Germany and France. In terms of social attitudes, Russia shows the most traditional attitudes toward 
marriage and gender roles. Finally, different housing systems have evolved in the four countries (Lawson and Milligan 2007; Norris and Shiels 2007). France has a welldeveloped public housing system, whereas home ownership and a private rental sector dominate the market in Australia and Germany. Russians have encountered the severest housing deprivation problems.

\section{Table 1: Contextual characteristics by country}

\begin{tabular}{|c|c|c|c|c|}
\hline $\begin{array}{l}\text { Country } \\
\text { Survey year }\end{array}$ & $\begin{array}{c}\text { Australia } \\
2005-6\end{array}$ & $\begin{array}{c}\text { France } \\
2005\end{array}$ & $\begin{array}{c}\text { Germany } \\
2005\end{array}$ & $\begin{array}{c}\text { Russia } \\
2004\end{array}$ \\
\hline GDP per capita (2005, PPP, current, WDI) & 31794.0 & 30386.0 & 29461.0 & 10845.0 \\
\hline GINI indexes (World Bank) & 33.2 & 31.4 & 31.2 & 37.1 \\
\hline Unemployment rate (\%, total, WDI) & 4.9 & 8.9 & 11.1 & 7.8 \\
\hline \multicolumn{5}{|l|}{ Social spending \% in GDP } \\
\hline Total (IMF) & 16.4 & 29.6 & 28.1 & 11.5 \\
\hline Family cash and kinds benefits (OECD) & 2.7 & 3.0 & 2.1 & - \\
\hline \multicolumn{5}{|l|}{ Family policy indexes } \\
\hline Public child care (around 2000, Fuwa and Cohen 2007) & 0.03 & 0.83 & $0.81 / 0.31^{\mathrm{a}}$ & 0.38 \\
\hline Direct/indirect cash support for families (Gauthier 2002/3) & 9.8 & 12.7 & 21.2 & - \\
\hline Maternity leave (Gauthier 2002/3) & 0.0 & 16.0 & 14.0 & - \\
\hline Crude marriage rate (UN) & 5.4 & 4.5 & 4.7 & 6.8 \\
\hline Crude divorce rate (UN) & 2.6 & 2.5 & 2.4 & 4.4 \\
\hline Total fertility rate (UN) & 1.8 & 1.9 & 1.3 & 1.3 \\
\hline \multicolumn{5}{|l|}{ Cohabitation indexes } \\
\hline \% ever cohabited, 18-44 (ESS 2002-2006, Soons and Kalmijn 2009) & - & 42.7 & 36.3 & 23.3 \\
\hline \% cohabiting, 18-44 (ESS 2002-2006, Soons and Kalmijn 2009) & - & 35.8 & 24.1 & 13.5 \\
\hline \multicolumn{5}{|l|}{ Female labor force } \\
\hline Economically active rate, $25-54$ (ILO) & 74.0 & 80.7 & 79.0 & 85.2 \\
\hline Full time, 25-54 (ISSP 2002) & 37.4 & 58.2 & 44.2 & 64.9 \\
\hline Part time, 25-54 (ISSP 2002) & 30.4 & 22.6 & 18.5 & 11.6 \\
\hline \multicolumn{5}{|l|}{ Housing indicators } \\
\hline Percent, ownership (GGS 2004-2006) & 65.8 & 59.3 & 44.7 & 65.1 \\
\hline Mean subjective satisfaction of dwelling quality (GGS 2004-2006) & 7.8 & 7.8 & 8.0 & 6.0 \\
\hline
\end{tabular}

Notes: Data sources: World Development Indicators (World Bank 2012); All the GINIs Dataset (World Bank 2010); Government Finance Statistics (International Monetary Fund 2004, 2005, 2006); OECD Social Expenditure Database (OECD 2012); UN Demographic Yearbook (UN 2012); ILO Labour Statistics (ILO 2012); International Social Survey Programme Family and Changing Gender Roles III (ISSP 2002); Generation and Gender Survey Wave 1 (United Nations 2014). a: 0.81: East Germany; 0.31: West Germany.

\section{Methods}

\subsection{The sample}

The data come from the first wave of the Generations and Gender Survey (GGS) conducted between 2002 and 2009 (United Nations 2014). The GGS is a set of comparative surveys of respondents aged 18-79 in 19 countries. The GGS collected 
Tai, Baxter \& Hewitt: Do co-residence and intentions make a difference?

nationally representative samples on topics including fertility, partnership, household composition, economic activity, housing, wellbeing, and attitudes by means of face-toface interviews with individuals. The respondents provided information on themselves, their residential and non-residential partners, other household members, and nonresidential family members.

We selected Australia, France, Germany, and Russia (2004-2006) for the study because these countries had comparable data available, but also a variety of institutional contexts. Analysis was limited to coupled heterosexual respondents who were either legally married, cohabiting, or living apart together. Same-sex respondents were excluded from the analyses because there were only a few cases $(n=102)$ and it is likely that homosexual and heterosexual couples are motivated to form different types of relationships and have different relationship outcomes due to uncontrolled factors (e.g., marital law). In addition, the selection of the analytic sample accommodates the following considerations. First, non-marital relationships, such as cohabitation, are uncommon among older adults (Brown and Booth 1996). Our preliminary analyses show that only about $10 \%$ of coupled respondents older than 55 were in a cohabiting or LAT relationship. Second, unlike marital unions, most non-marital unions end (through marriage or dissolution) within several years (Bumpass and Sweet 1989; Heuveline and Timberlake 2004). A study by Heuveline and Timberlake (2004) shows that the estimated median cohabitation spell of never-married women in 11 countries is 2.4 years. Considering relationship satisfaction as partially a function of duration, some previous studies restricted analyses to both marital and non-marital couples in relationships of 10 years or less (e.g., Brown 2003; Nock 1995). On the other hand, international studies suggest the relatively high prevalence and longer duration of nonmarital cohabitation in European countries such as France and Sweden (Köppen 2011; Sobotka and Toulemon 2008). For example, a study by Köppen (2011) shows that about 50\% of French women born between 1975 and 1980 still cohabited with their partners after eight years of non-marital cohabitation. Also, the GGS data show that almost $20 \%$ of cohabiters without marriage plans reported their cohabitation spell to be 15 years or longer. Given the concerns with the low incidence of non-marital unions among older respondents and prolonged non-marital relationships in some European countries, we selected respondents between 18 and 55 years of age and in unions of no more than 15 years. There were 11,145 respondents who fit our inclusion criteria.

The final analytic sample excluded 1,214 respondents with missing values on relationship satisfaction. There were 543 French respondents who were not asked about their relationship satisfaction because their partners were present during the interview. This rule was applied equally to all French respondents in marital, cohabiting, and LAT unions. Given that our main research goal questions how the gap in satisfaction levels between marital and non-marital unions varies across the four countries, it is unlikely 
that the exclusion of the 543 respondents will lead to biased estimates. The remaining 671 missing cases from all of the four countries did not answer, refused to answer, or answered "do not know" to the question on relationship satisfaction. Finally, we excluded respondents with missing data on key independent variables $(n=327)$. Our final analytical sample comprised 4,058 men and 5,546 women. Australia had the smallest sample ( $\mathrm{n}=771$ men and 948 women), while Russia had the largest $(n=1,421$ men and 1,875 women).

For robustness checks, we conducted additional analyses with multiple imputation methods and the results were similar to the results we presented here (results available on request). However, data imputation is considered an appropriate strategy when observations are missing at random (MAR) or missing completely at random (MCAR) (Acock 2005). Given our limited knowledge of the respondents with missing data, we decided to exclude missing values from our final models, with the exception of missing values on the respondent's and partner's education. We have a more detailed discussion on the coding of missing values on education in Section 3.3.2.

\subsection{Dependent variable}

Our dependent variable, relationship satisfaction, is measured by the question "How satisfied are you with your relationship with your partner/spouse?” Responses range from completely unsatisfied (0) to completely satisfied (10). We did not include other measures to assess relationship quality, such as disagreements between couples or the intention of breaking-up, because these variables are not available for all four countries.

\subsection{Independent variables}

\subsubsection{Relationship type}

The key independent variable is the respondent's union type. This was classified into five types: legally married, cohabiting and intending to marry, cohabiting but not intending to marry, in a LAT relationship and intending to marry or live together, and finally in a LAT relationship but not intending to marry or live together. The construction of union type was based on the following questions: "Does the respondent live with a partner?”, "Are you currently having an intimate (couple) relationship with someone you're not living with?”, and "Are you and he/she legally married?” Another two questions measured the respondent's intention to marry or cohabit: "Do you intend 
Tai, Baxter \& Hewitt: Do co-residence and intentions make a difference?

to marry somebody/ your partner during the next 3 years?", and "Do you intend to start living with a partner/your partner during the next 3 years?”

\subsubsection{Controls}

We control for several other factors found to be important for relationship formation and satisfaction. Longer union duration is also found to lower satisfaction for both married and cohabiting couples (Brown and Booth 1996; Nock 1995). Relationship duration, coded in years, was constructed from the difference between the survey year and the year when the respondent started the current relationship. The measurement of relationship duration, however, differs between residential and non-residential couples. The GGS consolidated duration item measures the time span in which a residential couple lived together and the time span from when a non-residential couple started their relationship. To investigate the non-linear changes in relationship satisfaction over the relationship course (Wiik, Keizer, and Lappegård 2012), duration, the respondent's age, and their squares are added to the models. Although middle-aged and older individuals are more likely to have longer relationships, the correlation between age and duration was not high $(r=0.4, p<.001, n=9,604)$. The partner's age was not included because the deletion of cases without information on partner's age removed the majority of Australian LAT relationships from the analyses.

Economic factors, such as employment status and education, are also important for relationship satisfaction. Dual-earner arrangements might lead to more work-family conflicts and increase the tension in relationships, although wives' earnings contribute to the economic wellbeing of families and may lead to higher relationship satisfaction (Perry-Jenkin, Repetti, and Crouter 2000). Work status was included as a series of dummy variables indicating whether the respondent and their partner were: $1=$ employed (i.e., employed or self-employed, on maternity, parental or childcare leave, helping family member in a family business or a farm, military or social service, and pension workers), 2 = unemployed, or $3=$ not in the labor force (i.e., in school or in vocational training, ill or disabled for a long time or permanently, retired, looking after the home or family, and other).

Respondent's and partner's educational attainment were classified into the following categories: low (ISCED 0-2), medium (ISCED 3-4), and high (ISCED 5-6) (UNESCO 2012). It should be noted that 1,121 respondents did not provide sufficient information on the partner's educational attainment (including "system missing," "other education," "can't determine," "still at school"). Preliminary analyses show that these cases reported significantly lower levels of satisfaction than non-missing cases. This suggests that these cases might be systematically different from non-missing cases and 
deletion or imputation could lead to biased estimates. We therefore added a "missing/unclear" category to our education variables for these cases. Because both respondent and partners education were included in our models, we tested them for collinearity; they were not highly correlated $(r=0.36, n=9,604)$.

Health status was measured using the respondent's subjective health status, ranging from very bad $(=1)$ to very good $(=5)$. It should be noted that Australia's health scale measure ranged from excellent to bad and therefore this was recoded to be consistent with the responses categories in the other countries. We also differentiated between respondents who had experienced a previous cohabiting or marital relationship (coded 1) from those who had no previous cohabiting or marital relationships. This measure of previous relationships excluded LAT relationships, because the Australian relationship history data did not include LAT relationships.

We include measures of attitudes toward gender roles and family life as previous research has found these are important for relationship satisfaction (Amato and Booth 1995; Amato and Rogers 1999; Wilcox and Nock 2006). Two items were included: "It is all right for an unmarried couple to live together even if they have no interest in marriage." and "If a woman earns more than her partner, it is not good for the relationship." The response categories for the two variables were inconsistent across the four countries, and the variables were dichotomized to harmonize the measures where more liberal responses were scored 1 , with a referent of traditional attitudes.

Previous research has shown that the presence of children can have a negative impact on relationship satisfaction (Brown 2003; Brown and Booth 1996; Glenn and McLanahan 1982; Stanley and Markman 1992; Willetts 2006). A dummy was included for the presence of dependent children aged $<14(1=$ yes $)$ in the respondent's household, including biological, step, and adoptive children with current or previous partners. Housing tenure was measured as a binary variable (home owner=1). Subjective satisfaction with current dwellings ranged from not satisfied at all $(=0)$ to completely satisfied $(=10)$. We included this measure, as variations in satisfaction with housing may be related to motivations for living apart together versus co-residential unions. Finally, country dummies were included to examine variations in relationship satisfaction across the four countries.

Information on race/ethnicity and religious affiliations was missing for Australian respondents and therefore these variables were excluded from the analyses.

\subsection{Analytic strategy}

Analysis proceeded in two main stages, descriptive and multivariate regressions. First, we conducted bivariate analysis comparing differences in socio-demographics across 
countries. Second, we estimated a series of ordinary least squares regression models. The distribution of relationship satisfaction is highly skewed to the left, which violates assumptions of normality, linearity, and equal distances between satisfaction categories. In additional analyses, we estimated ordered logit models. The results for key predictors including union type and country dummies were generally similar to those based on linear regression estimation (results available on request) and our final analyses were conducted using OLS regressions.

Two main models were estimated. The first model examined the associations between relationship type and relationship satisfaction, controlling for country, individual and household characteristics. In the second model, we examined country differences in the effects of union type on relationship satisfaction by including interaction terms between country and union type in the models. For this analysis we used Germany as the reference group. The analyses were conducted separately for men and women. Additional models including gender interactions for all covariates were estimated to test for significance in any estimated gender differences.

\section{Results}

\subsection{Descriptive results}

Table 2 reports descriptive statistics for individual and couple level characteristics. On average respondents reported scores of 8 or higher on a 10-point scale, indicating high levels of satisfaction with their relationships. Interestingly, Russian women reported the lowest levels of relationship satisfaction, with an average of 7.63. French, German, and Russian men reported higher levels of satisfaction than their female counterparts $(\mathrm{p}<.05)$, while there were no significant differences between Australian men and women.

The majority of the respondents were legally married, employed, and had employed partners. Cohabitation was the most common in France, where more than $30 \%$ of respondents were in non-marital cohabiting unions. Interestingly, cohabitation without marriage plans was more prevalent than cohabitation with marriage plans in France and Germany, whereas the majority of cohabiters intended to marry within three years in Russia and Australia. This suggests that non-marital cohabitation is likely to be a more permanent union in France and Germany, but a transition to marriage in Australia and Russia. For LAT relationships, the descriptive data indicate that respondents in LAT relationships and intending to live together or marry were more common across all countries than those in LAT unions not planning to marry or 
cohabit. Compared to the other three countries, LAT unions without marriage or cohabitation plans were more common in Russia.

The average union durations ranged from 5.6 to 7.3 years. Women in France, Russia, and Australia had higher levels of educational attainment than women in Germany. On average, $77 \%$ and $65 \%$ of the respondents reported liberal views about cohabitation and gender roles, although Russian respondents reported the most conservative attitudes. About $19 \%$ to $38 \%$ of respondents had experienced at least one marital or cohabiting relationship prior to their current partnership. Home ownership was more common in Australia than in other countries. Russian respondents were the least satisfied with their present dwellings (5.3-5.6 out of 10).

We also provide results for means on all variables across union type (see Appendix). As expected, cohabiters and those in LAT relationships had shorter union spells than married couples. Compared with married and cohabiting respondents, those in LAT relationships reported the lowest levels of employment, home ownership, and employed partners. On average, cohabiters had lower educational attainment and reported less traditional attitudes toward cohabitation and gender roles than married or LAT respondents.

Table 2: Individual and household characteristics: means by country and gender

\begin{tabular}{lrrrrrrrrrr}
\hline $\begin{array}{l}\text { Country } \\
\text { Variable }\end{array}$ & Total & \multicolumn{2}{c}{ Australia } & \multicolumn{2}{c}{ France } & \multicolumn{2}{c}{ Germany } & \multicolumn{2}{c}{ Russia } \\
N & & Men & Women & Men & Women & Men & Women & Men & Women \\
\hline $\mathrm{N}$ & 9604 & 771 & 948 & 810 & 1264 & 1056 & 1459 & 1421 & 1875 \\
Relationship satisfaction & 8.33 & 8.10 & 8.15 & 8.61 & 8.44 & 8.83 & 8.67 & 8.48 & 7.63 \\
Legally married & 0.53 & 0.54 & 0.54 & 0.46 & 0.42 & 0.54 & 0.63 & 0.57 & 0.54 \\
Cohabiting with intention to get married & 0.12 & 0.19 & 0.17 & 0.13 & 0.13 & 0.09 & 0.08 & 0.13 & 0.11 \\
Cohabiting without intention to get married & 0.11 & 0.04 & 0.04 & 0.16 & 0.21 & 0.11 & 0.12 & 0.07 & 0.10 \\
LAT with intention to marry or live together & 0.16 & 0.20 & 0.19 & 0.19 & 0.19 & 0.17 & 0.11 & 0.14 & 0.13 \\
LAT without intention to marry or live & & & & & & & & & \\
together & 0.08 & 0.04 & 0.05 & 0.06 & 0.06 & 0.09 & 0.06 & 0.09 & 0.12 \\
Duration & 6.33 & 5.59 & 5.61 & 6.54 & 6.35 & 6.51 & 7.34 & 6.13 & 6.18 \\
Respondent's age & 33.45 & 35.50 & 33.71 & 35.19 & 33.49 & 34.55 & 33.72 & 32.08 & 31.89 \\
Respondent's education & & & & & & & & & \\
$\quad$ Low & & & & & & & & & & \\
$\quad$ Medium & 0.11 & 0.18 & 0.22 & 0.12 & 0.13 & 0.09 & 0.12 & 0.08 & 0.05 \\
$\quad$ High & 0.48 & 0.46 & 0.36 & 0.50 & 0.41 & 0.57 & 0.58 & 0.53 & 0.42 \\
$\quad$ Missing/unclear & 0.37 & 0.36 & 0.42 & 0.37 & 0.46 & 0.27 & 0.24 & 0.33 & 0.46 \\
\hline
\end{tabular}


Tai, Baxter \& Hewitt: Do co-residence and intentions make a difference?

Table 2: (Continued)

\begin{tabular}{|c|c|c|c|c|c|c|c|c|c|}
\hline \multirow{2}{*}{$\begin{array}{l}\text { Country } \\
\text { Variable }\end{array}$} & \multirow[t]{2}{*}{ Total } & \multicolumn{2}{|c|}{ Australia } & \multicolumn{2}{|c|}{ France } & \multicolumn{2}{|c|}{ Germany } & \multicolumn{2}{|c|}{ Russia } \\
\hline & & Men & Women & Men & Women & Men & Women & Men & Women \\
\hline \multicolumn{10}{|l|}{ Respondent's work status } \\
\hline Employed & 0.76 & 0.91 & 0.71 & 0.87 & 0.75 & 0.78 & 0.66 & 0.82 & 0.72 \\
\hline Unemployed & 0.07 & 0.02 & 0.03 & 0.07 & 0.08 & 0.10 & 0.08 & 0.08 & 0.08 \\
\hline Others not in the labor force & 0.16 & 0.07 & 0.26 & 0.06 & 0.16 & 0.13 & 0.26 & 0.09 & 0.20 \\
\hline Respondent's general health & 4.02 & 4.38 & 4.47 & 4.24 & 4.18 & 4.28 & 4.25 & 3.61 & 3.40 \\
\hline Respondent's attitude toward cohabitation & 0.77 & 0.80 & 0.82 & 0.80 & 0.81 & 0.85 & 0.87 & 0.69 & 0.63 \\
\hline Respondent's gender attitude & 0.65 & 0.81 & 0.81 & 0.78 & 0.73 & 0.70 & 0.67 & 0.44 & 0.50 \\
\hline Ever married or cohabited & 0.30 & 0.23 & 0.25 & 0.37 & 0.35 & 0.19 & 0.25 & 0.29 & 0.38 \\
\hline \multicolumn{10}{|l|}{ Partner's education } \\
\hline Low & 0.10 & 0.22 & 0.20 & 0.13 & 0.14 & 0.14 & 0.07 & 0.01 & 0.04 \\
\hline Medium & 0.41 & 0.32 & 0.34 & 0.41 & 0.44 & 0.58 & 0.57 & 0.26 & 0.37 \\
\hline High & 0.37 & 0.42 & 0.38 & 0.43 & 0.38 & 0.16 & 0.32 & 0.48 & 0.37 \\
\hline Missing/unclear & 0.12 & 0.04 & 0.08 & 0.03 & 0.03 & 0.11 & 0.04 & 0.25 & 0.22 \\
\hline \multicolumn{10}{|l|}{ Partner's work status } \\
\hline Employed & 0.79 & 0.73 & 0.89 & 0.76 & 0.87 & 0.60 & 0.84 & 0.69 & 0.88 \\
\hline Unemployed & 0.06 & 0.03 & 0.02 & 0.07 & 0.06 & 0.06 & 0.08 & 0.07 & 0.06 \\
\hline Others not in the labor force & 0.15 & 0.24 & 0.08 & 0.17 & 0.07 & 0.34 & 0.09 & 0.24 & 0.06 \\
\hline Presence of minor children & 0.56 & 0.48 & 0.52 & 0.54 & 0.54 & 0.46 & 0.61 & 0.57 & 0.63 \\
\hline Home ownership & 0.50 & 0.64 & 0.62 & 0.47 & 0.44 & 0.35 & 0.39 & 0.57 & 0.56 \\
\hline Subjective dwelling satisfaction & 6.87 & 7.44 & 7.56 & 7.41 & 7.61 & 7.66 & 7.88 & 5.56 & 5.33 \\
\hline
\end{tabular}

\subsection{Regression results}

Figures 1 and 2 present the observed relationship satisfaction mean scores by union type, gender, and country. On average, women reported lower levels of satisfaction than men in the four countries (all differences were significant at $\mathrm{p}<.001$ ). Generally speaking, married respondents and cohabiters with marriage plans were more satisfied with their relationships than cohabiters without marriage plans and LAT respondents, while LAT respondents without marriage or cohabitation plans were the least satisfied in most countries. There were no significant differences in relationship satisfaction between married respondents and cohabiters with marriage plans for men and women and for all countries. Interestingly, Russian women in LAT relationships and with cohabitation or marriage plans were more satisfied than cohabiting Russian women without intention to marry $(\mathrm{p}<.001)$, but the difference between cohabiters without marriage plans and LAT respondents intending to cohabit or marry was not significant for women in the other three countries and for men in all countries. In terms of country 
differences, German respondents were the most satisfied with their relationships, followed by their French, Australian, and Russian counterparts.

Figure 1: Observed relationship satisfaction mean scores by union type and country: men's reports

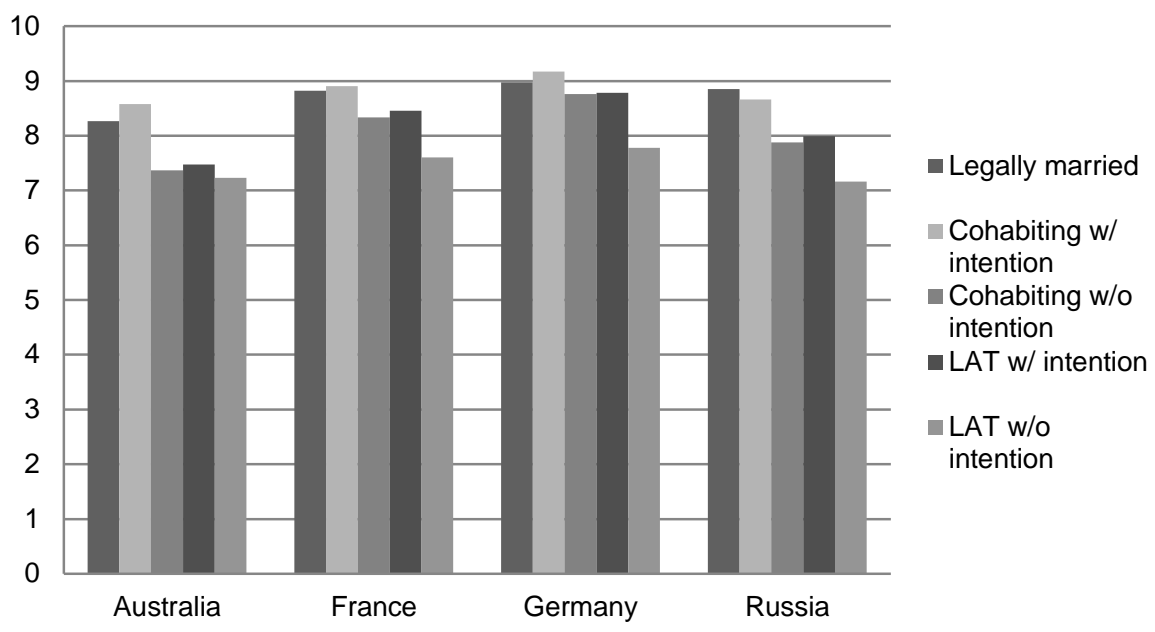

Figure 2: Observed relationship satisfaction mean scores by union type and country: women's reports

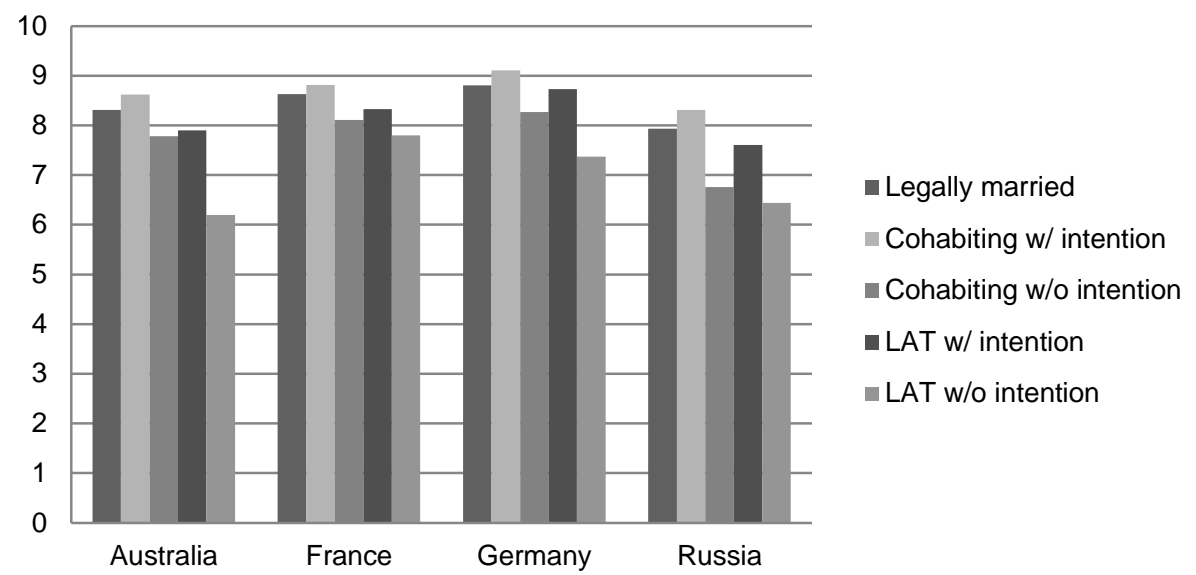


Tai, Baxter \& Hewitt: Do co-residence and intentions make a difference?

In Table 3 we present the multivariate ordinary least squares regression models predicting relationship satisfaction separately for men and women. All things being equal, compared to married respondents, all non-marital couples except for cohabiters with marriage plans were significantly less satisfied with their relationships $(\mathrm{p}<.001)$. Additional analyses (results not shown) showed that there was no significant difference in satisfaction levels between cohabiters without marriage plans and LAT respondents with plans to marry or live together and that LAT respondents without plans to marry or live together were the least satisfied compared to their counterparts in other types of unions (all differences significant at $\mathrm{p}<.001$ ).

As expected, country context was also important for explaining variations in levels of relationship satisfaction. Compared to Germans, Australian and French respondents reported lower levels of satisfaction $(\mathrm{p}<.001$ and $\mathrm{p}<.05$ respectively). Additional analyses (results not shown) show that Australian men and women were less satisfied with their relationships than their German, French, and Russian counterparts (all differences at $\mathrm{p}<.001)$. Russian women scored lower than German women $(\mathrm{p}<.001)$, but there were no significant differences in satisfaction levels between Russian and German men.

Table 3: OLS regression models for relationship satisfaction

\begin{tabular}{|c|c|c|c|c|}
\hline \multirow[t]{2}{*}{ Variable } & \multicolumn{2}{|c|}{ Men } & \multicolumn{2}{|c|}{ Women } \\
\hline & Coef. & SE & Coef. & SE \\
\hline \multicolumn{5}{|l|}{ Union type (ref: legally married) } \\
\hline Cohabiting with intention to get married & -0.079 & 0.087 & -0.036 & 0.087 \\
\hline Cohabiting without intention to get married & $-0.702^{\star \star \star}$ & 0.098 & $-0.878^{\star \star \star}$ & 0.085 \\
\hline LAT with intention to marry or live together & $-0.904^{\star \star *}$ & 0.095 & $-0.737^{\star \star \star}$ & 0.088 \\
\hline LAT without intention to marry or live together & $-1.643^{\star \star \star}$ & 0.118 & $-1.740^{* \star *}$ & 0.106 \\
\hline Duration & -0.027 & 0.023 & $-0.090^{\star * *}$ & 0.021 \\
\hline Duration squared & 0.001 & 0.001 & $0.003^{*}$ & 0.001 \\
\hline Respondent's age & -0.028 & 0.025 & $-0.053^{\star}$ & 0.024 \\
\hline Respondent's age squared & 0.000 & 0.000 & $0.001^{*}$ & 0.000 \\
\hline \multicolumn{5}{|l|}{ Respondent's education (ref: high) } \\
\hline Low & $0.241^{*}$ & 0.094 & 0.008 & 0.089 \\
\hline Medium & $0.125^{\star}$ & 0.060 & -0.010 & 0.058 \\
\hline Missing/unclear & -0.015 & 0.141 & -0.067 & 0.137 \\
\hline \multicolumn{5}{|l|}{ Respondent's work status (ref: employed) } \\
\hline Unemployed & -0.063 & 0.100 & $-0.251^{*}$ & 0.097 \\
\hline Others not in the labor force & 0.029 & 0.100 & 0.072 & 0.062 \\
\hline Respondent's general health & $0.271^{\star \star \star}$ & 0.038 & $0.265^{\star \star \star}$ & 0.037 \\
\hline Respondent's attitude toward cohabitation & -0.048 & 0.063 & -0.048 & 0.061 \\
\hline Respondent's gender attitude & $0.258^{\star \star \star}$ & 0.056 & $0.284^{\star \star \star}$ & 0.052 \\
\hline
\end{tabular}


Table 3: (Continued)

\begin{tabular}{|c|c|c|c|c|}
\hline \multirow[t]{2}{*}{ Variable } & \multicolumn{2}{|c|}{ Men } & \multicolumn{2}{|c|}{ Women } \\
\hline & Coef. & SE & Coef. & SE \\
\hline Ever married or cohabited & -0.021 & 0.069 & 0.007 & 0.066 \\
\hline \multicolumn{5}{|l|}{ Partner's education (ref: high) } \\
\hline Low & -0.145 & 0.097 & $-0.283^{\star \star}$ & 0.094 \\
\hline Medium & -0.019 & 0.064 & $-0.186^{\star \star}$ & 0.059 \\
\hline Missing/unclear & -0.128 & 0.089 & -0.150 & 0.089 \\
\hline \multicolumn{5}{|c|}{ Partner's work status (ref: employed) } \\
\hline Unemployed & 0.074 & 0.110 & $-0.433^{\star \star \star}$ & 0.105 \\
\hline Others not in the labor force & -0.005 & 0.063 & $-0.268^{\star \star}$ & 0.098 \\
\hline Presence of minor children & $-0.178^{\star}$ & 0.071 & $-0.190^{\star \star}$ & 0.063 \\
\hline Home ownership & -0.072 & 0.056 & -0.105 & 0.054 \\
\hline Subjective dwelling satisfaction & $0.085^{\star \star \star}$ & 0.011 & $0.109^{\star \star \star}$ & 0.011 \\
\hline \multicolumn{5}{|l|}{ Country (ref: Germany) } \\
\hline Australia & $-0.876^{\star \star \star}$ & 0.082 & $-0.737^{\star \star \star}$ & 0.081 \\
\hline France & $-0.182^{\star}$ & 0.079 & $-0.148^{\star}$ & 0.072 \\
\hline Russia & 0.039 & 0.084 & $-0.482^{\star \star \star}$ & 0.083 \\
\hline Constant & $8.021^{\star \star \star}$ & 0.490 & $8.603^{\star \star \star}$ & 0.472 \\
\hline R Square & \multicolumn{2}{|c|}{0.125} & \multicolumn{2}{|c|}{0.165} \\
\hline $\mathrm{N}$ & \multicolumn{2}{|c|}{4058} & \multicolumn{2}{|c|}{5546} \\
\hline
\end{tabular}

Note: Significance-level (two-tailed): ${ }^{*} p<.05,{ }^{\star \star} p<.01,{ }^{\star \star \star} p<.001$.

Many of the control variables were also important for explaining relationship satisfaction. For women, the association between relationship satisfaction and relationship duration and age were not linear: satisfaction declined as age went up and remained stable at older ages; union duration presented a non-linear connection with relationship satisfaction. Partner's SES status had a stronger effect on women's levels of satisfaction than was the case for men. Women reported lower levels of satisfaction when their partners were not in the labor force or if their partners had lower educational attainment. This may be because men tend to be the main breadwinners in many households and their socio-economic position will more strongly influence the resources and economic wellbeing of the couple. At the same time, men who are not employed may have lower self esteem and wellbeing, which in turn may influence couple dynamics and relationship satisfaction. Women's unemployment was also negatively associated with their relationship satisfaction, again perhaps due to other factors such as wellbeing, which may impact couple dynamics. Somewhat unexpectedly, men with low or medium educational attainment were more satisfied with their relationship, compared to their highly educated counterparts. However, the expectation of a positive association between higher education and relationship 
satisfaction is based on the fact that people with higher levels of education tend to have better employment prospects, income, and health which are mostly controlled in our analyses (Amato and Booth 1997; Brown 2003; Farley 1996; Wiik, Keizer, and Lappegård 2012).

Similar to previous findings, respondents with better health had higher levels of relationship satisfaction, although the causal direction is not clear here. Both men and women who held less traditional gender views reported more satisfaction with their relationships. The presence of young children in the household reduced the level of relationship satisfaction for both men and women. Housing satisfaction increased relationship satisfaction, although homeownership was not associated with relationship satisfaction.

Finally, additional models including gender interactions for all covariates (results not shown) show that women reported lower levels of relationship satisfaction than men $(\mathrm{p}<.001)$. Russian women were significantly less satisfied with their relationships $(\mathrm{p}<.001)$ than Russian men. In addition, women with non-working partners also reported lower levels of satisfaction than their male counterparts $(\mathrm{p}<.05)$. In contrast to our expectations, we did not find significant gender differences in relationship satisfaction by union type. In other words, the differences in satisfaction between married respondents and those in the four non-marital unions were patterned in the same way for men and women. Other explanatory variables, including the respondent's health, gender attitudes and employment status, and the presence of children in the household, had similar impacts on relationship satisfaction for men and women.

We further examined country level differences in Table 4, which presents the results of OLS models with interaction terms between union type and country. The analyses test the differences in satisfaction levels between married and other nonmarital respondents in Australia, France, and Russia, compared to German respondents. The results show that relative to Germans, Russian cohabiters without marriage plans $(\mathrm{p}<.01)$ and LAT respondents with marriage or cohabitation plans $(\mathrm{p}<.1)$ were less satisfied with their relationships than married respondents. Further, Russian males in LAT unions not intending to marry or cohabit scored lower than their married counterparts $(\mathrm{p}<.05)$. The difference in satisfaction between LAT respondents with marriage or cohabitation plans and their married counterparts was more substantial in Australia than in Germany $(\mathrm{p}<.05)$. Also, relative to German men, Australian men who were cohabiting without plans were less satisfied than married males $(\mathrm{p}<.1)$. Finally, the satisfaction gap between married women and those in LAT unions but without marriage or cohabitation plans was smaller in France than in Germany $(\mathrm{p}<.05)$. 
Table 4: OLS regression models for relationship satisfaction with interaction effects

\begin{tabular}{|c|c|c|c|c|}
\hline \multirow[t]{2}{*}{ Variable } & \multicolumn{2}{|c|}{ Men } & \multicolumn{2}{|c|}{ Women } \\
\hline & Coef. & SE & Coef. & SE \\
\hline \multicolumn{5}{|l|}{ Union type (ref: legally married) } \\
\hline Cohabiting $w /$ intention to get married & 0.008 & 0.180 & -0.035 & 0.177 \\
\hline Cohabiting w/o intention to get married & $-0.352^{\star}$ & 0.167 & $-0.691^{\star \star \star}$ & 0.151 \\
\hline LAT w/ intention to marry or live together & $-0.513^{\star \star}$ & 0.154 & $-0.440 \star \star$ & 0.167 \\
\hline LAT w/o intention to marry or live together & $-1.451^{\star \star \star}$ & 0.191 & $-1.806^{\star \star \star}$ & 0.207 \\
\hline \multicolumn{5}{|l|}{ Country (ref: Germany) } \\
\hline Australia & $-0.765^{\star \star \star}$ & 0.107 & $-0.632^{\star \star \star}$ & 0.104 \\
\hline France & -0.143 & 0.110 & -0.151 & 0.100 \\
\hline Russia & $0.301^{\star \star}$ & 0.104 & $-0.379^{\star \star \star}$ & 0.099 \\
\hline \multicolumn{5}{|l|}{$\begin{array}{l}\text { Interaction (country X union type, } \\
\text { Ref: German married respondents) }\end{array}$} \\
\hline Australia $X$ cohabiting $w /$ intention & 0.147 & 0.232 & -0.037 & 0.237 \\
\hline Australia $X$ cohabiting w/o intention & $-0.642+$ & 0.357 & 0.073 & 0.323 \\
\hline Australia X LAT w/ intention & $-0.591^{\star \star}$ & 0.208 & $-0.437^{\star}$ & 0.223 \\
\hline Australia X LAT w/o intention & 0.247 & 0.353 & -0.586 & 0.333 \\
\hline France $X$ cohabiting $w /$ intention & -0.039 & 0.246 & -0.125 & 0.234 \\
\hline France $X$ cohabiting w/o intention & -0.260 & 0.231 & -0.032 & 0.200 \\
\hline France X LAT w/ intention & -0.116 & 0.208 & -0.297 & 0.212 \\
\hline France $X$ LAT w/o intention & 0.091 & 0.305 & $0.722^{\star}$ & 0.300 \\
\hline Russia $X$ cohabiting $w /$ intention & -0.315 & 0.218 & 0.120 & 0.220 \\
\hline Russia X cohabiting w/o intention & $-0.632^{\star *}$ & 0.234 & $-0.570^{\star *}$ & 0.206 \\
\hline Russia X LAT w/ intention & $-0.721^{\star \star \star}$ & 0.190 & $-0.371+$ & 0.203 \\
\hline Russia X LAT w/o intention & $-0.528^{\star}$ & 0.237 & -0.004 & 0.241 \\
\hline Constant & $7.787^{\star \star \star}$ & 0.494 & $8.388^{\star \star \star}$ & 0.477 \\
\hline R-square & \multicolumn{2}{|c|}{0.133} & \multicolumn{2}{|c|}{0.170} \\
\hline$N$ & \multicolumn{2}{|c|}{4058} & \multicolumn{2}{|c|}{5546} \\
\hline
\end{tabular}

Notes: Net of other predictors including duration, the respondent's age, education, work status, health, attitude toward cohabitation and gender attitude; ever married or cohabited; partner's education and work status; the presence of minor children, home ownership and subjective dwelling satisfaction.

Significance-level (two-tailed): $+p<.01,{ }^{\star} p<.05,{ }^{\star \star} p<.01,{ }^{\star \star \star} p<.001$

In summary, the majority of couples, aged 18-55 were legally married. Consistent with previous studies (Brown and Booth 1996), legally married and cohabiting respondents with marriage plans were more satisfied with their relationships than respondents in other types of unions. Intentions are also important, and we find those in LAT relationships with no intentions of marriage or living together had the lowest satisfaction. Our findings support country differences in relationship satisfaction. In 
general, German respondents reported higher levels of relationship satisfaction than Australians, French respondents, and Russian women. Our results also imply that the effect of union type on relationship satisfaction is moderated by national context. Relative to German couples, the differences in satisfaction between married respondents and cohabiters without marriage plans or LAT respondents were more substantial in Australia and Russia. Finally, as the bivariate analyses revealed, Russian women in LAT relationships with intentions of marriage or living together were more satisfied than Russian women in cohabiting relationships with no intentions of marriage. This is consistent with the expectation that perhaps in countries where unmarried cohabitation is viewed negatively, those in LAT relationships may feel less societal pressure. Or it may be that intentions to marry are associated with greater relationship satisfaction amongst women in these LAT relationships, as this may indicate a stronger commitment to their relationship and the expectation of relationship stability.

\section{Discussion}

This paper examined variations in relationship satisfaction across union type and country. Demographic changes in patterns of union formation, combined with more liberal views and greater institutional support for non-marital relationships, provide more choices for union formation across many countries. Choice of union type may occur in response to institutional, couple, and individual factors. Relationship satisfaction is likely to be associated with these factors, as well as relationship experiences.

We have extended previous research on these issues by examining two kinds of non-marital relationships, cohabiters and those in LAT relationships, and have further differentiated these types according to their intentions to live together or marry. While not the only indicator of commitment to a relationship, intentions to marry or live together suggest the relationship is viewed as more enduring and likely to progress. This enables consideration of whether variations in relationship commitment are related to relationship satisfaction. We expected that stronger commitment would be positively associated with relationship satisfaction. Furthermore, we examined patterns by gender and in a range of countries that vary in socio-cultural context and degree of institutionalization and support for non-marital unions. Based on findings of previous studies of non-marital couples, we expected higher levels of relationship satisfaction amongst LAT respondents where there is stronger institutional support and normative acceptance of non-marital unions. Overall our results provided mixed support for these expectations. 
We have four core findings. First, relationship satisfaction varies according to both relationship type and intentions. On the whole, married respondents were the most satisfied and LAT respondents were the least satisfied, while cohabiters fell roughly in between these two groups. This provides broad support for the view that higher levels of relationship commitment, as measured by intentions, legal status, and co-residence, are related to higher levels of relationship satisfaction. However, there were some variations in these patterns by relationship intentions of cohabiters and LAT respondents. In accordance with previous research on the significance of commitment in cohabiting unions (e.g., Brown and Booth 1996; Wiik, Berhhardt, and Noack 2009), both cohabiting men and women planning to marry were as satisfied with their relationship as married couples. We also find that LAT men and women with marriage or cohabitation plans were as satisfied as cohabiters without marriage plans. Overall, those in LAT relationships who did not expect to marry or live with their partner within three years reported the lowest levels of relationship satisfaction.

Of course the discussion above implies that married couples are the most committed of all relationship types, a reasonable assumption given their willingness to commit to a legal partnership. But arguably the increasing incidence of marital separation and greater access to divorce may challenge this assumption. Previous research suggests that married couples also vary in terms of their intentions to stay married. Therefore, married couples may be heterogeneous in the same way as nonmarital couples. Union types mask a range of variations and similar to the argument made by Duncan and Phillips (2010: 132), it is important not to confuse changing union type with changing union experiences.

Second, we find interesting country differences in levels of relationship satisfaction. Germans reported the highest levels of relationship satisfaction, while Australians and Russian women reported the lowest levels. According to prior research, Eastern European men and women are usually found to be less happy than their counterparts in other countries (Soons and Kalmijn 2009). Even though the majority of Russian women work in full-time jobs and have higher educational attainment than their counterparts in other countries, social norms still support a strong malebreadwinner family model (Motiejunaite and Kravchenko 2008). Russian women tend to have long paid work and domestic hours (Zdravomyslova 1995). Since the transition to a market economy women have predominated among the unemployed. In addition, reduced social provisions and inadequate public childcare fell short of reconciling the competing demands of work and family (Samarina 2001). Moreover, lower social approval of non-marital partnerships may place further pressure on Russian women who are in unions without a formal commitment. All of these factors may contribute to lower levels of relationship satisfaction for Russian women. On the other hand, Russian men may benefit from a traditional division of domestic labor and the financial 
Tai, Baxter \& Hewitt: Do co-residence and intentions make a difference?

contribution from women's employment, as indicated by high levels of relationship satisfaction.

Australians were also less satisfied with their relationships than their German counterparts. Less comprehensive family policies and marginal social housing provisions might be important factors here. Finally, Germans' higher levels of satisfaction are mainly driven by the reports of married respondents and those in LAT relationships with cohabitation plans (results not shown). Although France and Germany are often grouped in the same cluster of conservative countries, in general, Germany has a higher level of religiosity and more traditional family values (Soons and Kalmijn 2009). Its family policies also support a traditional division of labor (EspingAndersen 1999; Gauthier 2002/3).

Third, we also find country differences in the association between union type and relationship satisfaction, showing some support for the view that countries with high levels of support for non-marital unions have the smallest differences in relationship satisfaction across union types. Germany and France were similar here, with few significant differences between these countries in levels of relationship satisfaction across union type. On the other hand, there was evidence that both Russia and Australia differed significantly from Germany with lower levels of relationship satisfaction amongst some non-marital unions compared to married respondents in Russia and Australia. As outlined above, both Australia and Russia have low levels of institutional support for non-marital unions and this may explain the low levels of relationship satisfaction amongst these non-traditional union types. A lack of cultural, political, and social support for intimate partnering outside of marriage may be associated with lower levels of relationship satisfaction for couples who live in non-traditional relationships through personal choice or circumstances beyond their control.

Fourth, although we find that overall women were less satisfied with their relationships than men, there are remarkably few significant differences in the impact of union type on satisfaction between men and women. In other words, it is not just that men and women share a similar ordering of levels of relationship satisfaction amongst the five union types, but also that there are no significant gender differences in the satisfaction gap between union types. There are some possible explanations for the similar pattern of the effect of union type on relationship satisfaction for men and women. It has been suggested that compared to women, LAT men might be much less satisfied than their married and cohabiting counterparts, given that married and cohabiting men may benefit more than men in LAT relationships from women's unpaid labor and care work. The expected larger gap in satisfaction between residential and non-residential relationships amongst men might be offset by the argument that women in less institutionalized unions might feel much less happy than men due to insecure financial support or lower levels of social approval of women's non-marital 
relationships. The greatest variation by gender was observed in Russia, where Russian women report much lower relationship satisfaction than Russian men, and lower levels than men and women in all other countries. As noted above, there are country specific reasons relating to social norms and changing political and economic structures.

Our paper has a number of limitations. First. we only examined data for four countries, which excludes possibilities for multilevel analyses. Second, due to data limitations, measures of income, earnings, partner's age, and religiosity are not included in the analyses. We are thus only able to include the spouse's educational attainment and work status. Third, our data are cross-sectional and therefore we are unable to disentangle issues of cause and effect or selection and endogeneity. Although we control for a number of potentially confounding variables in our analyses, we are unable to examine whether high levels of relationship satisfaction lead to entry into different kinds of relationships or vice versa. Fourth, there is debate amongst family scholars about whether LAT relationships are equivalent to other forms of marital and nonmarital partnerships, or whether they are a stage in the dating relationship and are more akin to dating couples (Duncan and Phillips 2010). However, as noted above, there is undoubtedly a great deal of variation within each of the categories investigated here, including married couples. In addition, unlike some previous studies, we are able to differentiate those in LAT relationships according to future intentions, thus presumably controlling some of these variations.

Despite these limitations, our paper provides important new information about variations in relationship satisfaction across union type, gender, and country context. In particular we have added to understanding about experiences within LAT relationships, a union type that has only recently begun to gain attention from family scholars. Further research that explores these patterns in a broader range of countries, as well as analyses using longitudinal data that enables issues of endogeneity to be controlled, will enhance our understanding of these issues further.

\section{Acknowledgements}

This research results from collaboration between members of the Relations-CrossNations (RCN)-network. RCN meetings have been supported by: (a) a grant from Utrecht University within the University of California-Utrecht University Collaborative Grant Program (2009), (b) an RFP-grant from the Population Association of America (2010/11), (c) a grant from the Spanish Ministry of Science (2010), and (d) grants from the Swiss National Science Foundation and FORS (2011).

This research was supported by funding from the Australian Research Council (DP0984787). 
Tai, Baxter \& Hewitt: Do co-residence and intentions make a difference?

\section{References}

Acock, A.C. (2005). Working with missing values. Journal of Marriage and Family 67: 1012-1028. doi:10.1111/j.1741-3737.2005.00191.x.

Amato, P.R. and Booth, A. (1995). Changes in gender role attitudes and perceived marital quality. American Sociological Review 60(1): 58-66. doi:10.2307/2096345.

Amato, P.R. and Booth, A. (1997). A generation at risk: Growing up in an era of family upheaval. Cambridge, MA: Harvard University Press.

Amato, P.R. and Rogers, S.J. (1999). Do attitudes toward divorce affect marital quality? Journal of Family Issues 20(1): 69-86. doi:10.1177/019251399020001004.

Batalova, J.A. and Cohen, P.N. (2002). Premarital cohabitation and housework: couples in cross-national perspective. Journal of Marriage and Family 64: 743-755. doi:10.1111/j.1741-3737.2002.00743.x.

Baxter, J. (2005). To marry or not to marry: marital status and the household division of labor. Journal of Family Issues 26(3): 300-321. doi:10.1177/0192513X04270 473.

Baxter, J., Hewitt, B., and Haynes, M. (2008). Life course transitions and housework: Marriage, parenthood, and time on housework. Journal of Marriage and Family 70: 259-272. doi:10.1111/j.1741-3737.2008.00479.x.

Bernard, J. (1972). The future of marriage. New Haven, CT: Yale University Press.

Blossfeld, H.-P. and Drobnič, S. (2001). Careers of couples in contemporary societies: from male breadwinner to dual earner families. Oxford: Oxford University Press.

Brown, S.L. (2003). Relationship quality dynamics of cohabiting unions. Journal of Family Issues 24(5): 583-601. doi:10.1177/0192513X03024005001.

Brown, S.L. and Booth, A. (1996). Cohabitation versus marriage: A comparison of relationship quality. Journal of Marriage and Family 58(3): 668-678. doi:10.2307/353727.

Brown, S.L. and Kawamura, S. (2010). Relationship quality among cohabitors and marrieds in older adulthood. Social Science Research 39: 777-786. doi:10.1016/j.ssresearch.2010.04.010. 
Budig, M. and England, P. (2001). The wage penalty for motherhood. American Sociological Review 66(2): 204-225. doi:10.2307/2657415.

Bumpass, L.L. and Sweet, J.A. (1989). National estimates of cohabitation. Demography 26: 615-625.

Chandola, T., Coleman, D.A., and Hiorns, R.W. (2002). Heterogeneous fertility patterns in the English-speaking world. Results from Australia, Canada, New Zealand and the United States. Population Studies 56(2): 181-200. doi:10.1080/00324720215929.

Cherlin, A. (2009). The marriage-go-round: the state of marriage and the family in America today. New York: Alfred A. Knopf.

Deacon, B. (ed.). (1992). The New Eastern Europe: Social policy past, present and future. London: Sage Publications.

Duncan, S. and Phillips, M. (2010). People who live apart together (LATs)—how different are they? The Sociological Review 58(1): 112-134. doi:10.1111/j.1467954X.2009.01874.x.

Esping-Andersen, G. (1999). Social foundations of postindustrial economies. Oxford: Oxford University Press. doi:10.1093/0198742002.001.0001.

Fajth, G. (1999). Social security in a rapidly changing environment: the case of the post-communist transformation. Social Policy \& Administration 33(4): 416-436. doi:10.1111/1467-9515.00161.

Farley, R. (1996). The new American reality: Who we are, how we got here, where we are going. New York: Russell Sage Foundation.

Fuwa, M. and Cohen, P.N. (2007). Housework and social policy. Social Science Research 36: 512-530. doi:10.1016/j.ssresearch.2006.04.005.

Gauthier, A.H. (2002/3). Family policies in industrialized countries: Is there convergence? Population 57: 447-474. doi:10.2307/3246635.

Gerber, T.P. and Berman, D. (2010). Entry to marriage and cohabitation in Russia, 1985-2000: Trends, correlates, and implications for the second demographic transition. European Journal of Population 26: 3-31. doi:10.1007/s10680-0099196-8.

Glenn, N.D. and McLanahan, S. (1982). Children and marital happiness: A further specification of the relationship. Journal of Marriage and the Family 44:63-72. doi:10.2307/351263. 
Gornick, J.C. and Meyers, M.K. (eds.). (2009). Gender inequality: Transforming family divisions of labor. London: Verso.

Gupta, S. (1999). The effects of transitions in marital status on men's performance of housework. Journal of Marriage and the Family 61(3):700-711. doi:10.2307/353571.

Haskey, J. and Lewis, J. (2006). Living-apart-together in Britain: Context and meaning. International Journal of Law in Context 2(1): 37-48. doi:10.1017/S1744552306001030.

Heuveline, P. and Timberlake, J.M. (2004). The role of cohabitation in family formation: the United States in a comparative perspective. Journal of Marriage and Family 66: 1214-1230. doi:10.1111/j.0022-2445.2004.00088.x.

Huston, T.L. and Melz, H. (2004). The case for (promoting) marriage: the devil is in the details. Journal of Marriage and Family 66: 943-958. doi:10.1111/j.00222445.2004.00064.x.

International Labour Organization. (2012). Labour Statistics. http://laborsta.ilo.org/.

International Monetary Fund. (2004). Government Finance Statistics Yearbook. Washington DC: International Monetary Fund.

International Monetary Fund. (2005). Government Finance Statistics Yearbook. Washington DC: International Monetary Fund.

International Monetary Fund. (2006). Government Finance Statistics Yearbook. Washington DC: International Monetary Fund.

International Social Survey Programme. (2002). Family and changing gender roles III. http://zacat.gesis.org/webview/index.jsp?object=http://zacat.gesis.org/obj/fStudy /ZA3880\%20.

Kalmijn, M. (2007). Explaining cross-national differences in marriage, cohabitation, and divorce in Europe, 1990-2000. Population Studies 61(3): 243-263. doi:10.1080/00324720701571806.

Karlsson, S.G. and Borell, K. (2002). Intimacy and autonomy, gender and ageing: Living apart together. Ageing International 27(4): 11-26. doi:10.1007/s12126002-1012-2.

Karlsson, S.G. and Borell, K. (2005). A home of their own. Women's boundary work in LAT-relationships. Journal of Aging Studies 19: 73-84. doi:10.1016/j.jaging. 2004.03.008. 
Kiernan, K. (2000). European perspectives on union formation. In: Waite, L.J., Bachrach, C., Hindin, M., Thompson, E., and Thornton, A. (eds.). The ties that bind: Perspectives on marriage and cohabitation. New York: Aldine De Gruyter: 40-58.

Kiernan, K. (2001). The rise of cohabitation and childbearing outside marriage in Western Europe. International Journal of Law, Policy and the Family 15: 1-21. doi:10.1093/lawfam/15.1.1.

Kiernan, K. (2004). Redrawing the boundaries of marriage. Journal of Marriage and Family 66: 980-987. doi:10.1111/j.0022-2445.2004.00068.x.

Köppen, K. (2011). Marriage and cohabitation in western Germany and France. [Ph.D. Thesis]. Rostock, Germany: University of Rostock and the Max Planck Institute for Demographic Research.

Lawson, J. and Milligan, V. (2007). International trends in housing and policy responses. AHURI Final Report No. 110. Melbourne, Australia: Australian Housing and Urban Research Institute.

Levin, I. (2004). Living apart together: A new family form. Current Sociology 52(2): 223-240. doi:10.1177/0011392104041809.

Levin, I. and Trost, J. (1999). Living apart together. Community, Work \& Family 2(3): 279-294. doi:10.1080/13668809908412186.

Liefbroer, A.C. and Dourleijn, E. (2006). Unmarried cohabitation and union stability: Testing the role of diffusion using data from 16 European countries. Demography 43(2): 203-221. doi:10.1353/dem.2006.0018.

Manning, W.D. and Smock, P.J. (2002). First comes cohabitation and then comes marriage? A research note. Journal of Family Issues 23(8): 1065-1087. doi:10.1177/019251302237303.

Michigami, M. (2011). Comparison of affordability of Russian and Japanese housing markets. Far Eastern Studies 10: 25-57.

Motiejunaite, A. and Kravchenko, Z. (2008). Family policy, employment and genderrole attitudes: A comparative analysis of Russia and Sweden. Journal of European Social Policy 18(1): 38-49. doi:10.1177/0958928707084453.

Nesporova, A. (2002). Why unemployment remains so high in Central and Eastern Europe. Geneva: ILO International Labour Office (Employment Paper; 2002/43). 
Tai, Baxter \& Hewitt: Do co-residence and intentions make a difference?

Nock, S.L. (1995). A comparison of marriages and cohabiting relationships. Journal of Family Issues 16(1): 53-76. doi:10.1177/019251395016001004.

Norris, M. and Shiels, P. (2007). Housing inequalities in an enlarged European Union: Patterns, drivers, implications. Journal of European Social Policy 17(1): 65-76. doi:10.1177/0958928707071893.

Oppenheimer, V.K., Kalmijn, M., and Lim, N. (1997). Men’s career development and marriage timing during a period of rising inequality. Demography 34(3): 311330. doi:10.2307/3038286.

Organization for Economic Co-operation and Development. (2012). OECD stat extracts. http://stats.oecd.org/.

Perry-Jenkins, M., Repetti, R.L., and Crouter, A.C. (2000). Work and family in the 1990s. Journal of Marriage and the Family 62: 981-998. doi:10.1111/j.17413737.2000.00981.x.

Reimondos, A., Evans, A., and Gray, E. (2011). Living-apart-together (LAT) relationships in Australia. Family Matters 87: 43-55.

Rhoades, G.K., Stanley, S.M., and Markman, H.J. (2012). A longitudinal investigation of commitment dynamics in cohabiting relationships. Journal of Family Issues 33(3): 369-390. doi:10.1177/0192513X11420940.

Roseneil, S. (2006). On not living with a partner: unpicking coupledom and cohabitation. Sociological Research Online 11. http://www.socresonline.org.uk/ 11/3/roseneil.html. doi:10.5153/sro.1413.

Samarina, O. (2001). The social protection of women and family policy in contemporary Russia. Problems of Economic Transition 44(1): 72-80.

Smock, P.J. (2000). Cohabitation in the United States: An appraisal of research themes, findings, and implications. Annual Review of Sociology 26:1-20. doi:10.1146/annurev.soc.26.1.1.

Sobotka, T. and Toulemon, L. (2008). Changing family and partnership behaviour: Common trends and persistent diversity across Europe. Demographic Research 19(6): 85-138. doi:10.4054/DemRes.2008.19.6.

Soons, J.P.M. and Kalmijn, M. (2009). Is marriage more than cohabitation? Well-being differences in 30 European countries. Journal of Marriage and Family 71: 1141-1157. doi:10.1111/j.1741-3737.2009.00660.x. 
Stanley, S.M. and Markman, H.J. (1992). Assessing commitment in personal relationships. Journal of Marriage and the Family 54(3): 595-608. doi:10.2307/353245.

Stanley, S.M., Rhoades, G.K., and Markman, H. J. (2006). Sliding versus deciding: Inertia and the premarital cohabitation effect. Family Relations 55: 499-509. doi:10.1111/j.1741-3729.2006.00418.x.

Stanley, S.M., Whitton, S.W., and Markman, H.J. (2004). Maybe I do: Interpersonal commitment and premarital or nonmarital cohabitation. Journal of Family Issues: 25(4): 496-519. doi:10.1177/0192513X03257797.

Strohm, C.Q., Seltzer, J.A., Cochran, S.D., and Mays, V.M. (2010). "Living apart together" relationships in the United States. Demographic Research 21(7): 177214. doi:10.4054/DemRes.2009.21.7.

Sweeney, M.M. (2002). Two decades of family change: the shifting economic foundations of marriage. American Sociological Review 67(1): 132-147. doi:10.2307/3088937

UNESCO (2012). International standard classification of education. http://www.uis.unesco.org/Education/Pages/international-standard-classificati on-of-education.aspx.

United Nations (2014). Generations and Gender Programme. http://www.ggp-i.org/.

United Nations (2012) Demographic yearbook. http://unstats.un.org/unsd/demographic/ products/dyb/dyb2.htm.

Wiik, K.A., Bernhardt, E., and Noack, T. (2009). A study of commitment and relationship quality in Sweden and Norway. Journal of Marriage and Family: 71: 465-477. doi:10.1111/j.1741-3737.2009.00613.x.

Wiik, K.A., Keizer, R., and Lappegård, T. (2012). Relationship quality in marital and cohabiting unions across Europe. Journal of Marriage and Family 74: 389-398. doi:10.1111/j.1741-3737.2012.00967.x.

Wilcox, W.B. and Nock, S.L. (2006). What's love got to do with it? Equality, equity, commitment and women's marital quality. Social Forces 84(3): 1321-1345. doi:10.1353/sof.2006.0076.

Willetts, M.C. (2006). Union quality comparisons between long-term heterosexual cohabitation and legal marriage. Journal of Family Issues 27(1): 110-127. doi:10.1177/0192513X05279986. 
Tai, Baxter \& Hewitt: Do co-residence and intentions make a difference?

World Bank. (2010). All the Ginis dataset. http://econ.worldbank.org/WBSITE/ EXTERNAL/EXTDEC/EXTRESEARCH/0,,contentMDK:22301380 pagePK:6 4214825 piPK:64214943 theSitePK:469382,00.html.

World Bank. (2012). The World Development Indicators. http://data.worldbank.org/ data-catalog/world-development-indicators.

Zdravomyslova, O. (1995). The position of women. In: Lane, D.S. (ed.). Russia in Transition. Harlow: Longman: 190-198. 


\section{Appendix: Individual and household characteristics: Means by country and union type}

\begin{tabular}{|c|c|c|c|c|c|c|c|c|c|c|c|c|}
\hline \multirow{2}{*}{$\begin{array}{l}\text { Country } \\
\text { Variable }\end{array}$} & \multicolumn{3}{|c|}{ Australia } & \multicolumn{3}{|c|}{ France } & \multicolumn{3}{|c|}{ Germany } & \multicolumn{3}{|c|}{ Russia } \\
\hline & Married & Cohabit & LAT & Married & Cohabit & LAT & Married & Cohabit & LAT & Married & Cohabit & LAT \\
\hline $\mathrm{N}$ & 929 & 374 & 416 & 898 & 661 & 515 & 1484 & 518 & 513 & 1814 & 683 & 799 \\
\hline Relationship & & & & & & & & & & & & \\
\hline Satisfaction & 8.29 & 8.42 & 7.49 & 8.71 & 8.46 & 8.23 & 8.87 & 8.75 & 8.35 & 8.34 & 7.91 & 7.31 \\
\hline Duration & 8.21 & 3.19 & 1.93 & 9.40 & 5.25 & 2.73 & 9.20 & 4.69 & 2.93 & 8.23 & 4.47 & 2.92 \\
\hline R's age & 36.27 & 32.37 & 32.52 & 35.46 & 32.46 & 34.05 & 35.76 & 33.22 & 30.03 & 31.87 & 33.73 & 30.70 \\
\hline $\begin{array}{l}\text { Female } \\
\text { Respondent's } \\
\text { education }\end{array}$ & 0.56 & 0.53 & 0.56 & 0.59 & 0.65 & 0.60 & 0.62 & 0.58 & 0.47 & 0.56 & 0.58 & 0.59 \\
\hline Low & 0.19 & 0.25 & 0.18 & 0.11 & 0.14 & 0.13 & 0.11 & 0.10 & 0.11 & 0.05 & 0.11 & 0.06 \\
\hline Medium & 0.35 & 0.44 & 0.48 & 0.43 & 0.47 & 0.46 & 0.60 & 0.57 & 0.51 & 0.45 & 0.53 & 0.46 \\
\hline High & 0.46 & 0.31 & 0.33 & 0.46 & 0.39 & 0.41 & 0.28 & 0.25 & 0.19 & 0.43 & 0.30 & 0.43 \\
\hline $\begin{array}{l}\text { Missing/unclear } \\
\text { Respondent's } \\
\text { work status }\end{array}$ & 0.00 & 0.00 & 0.01 & 0.00 & 0.00 & 0.00 & 0.01 & 0.08 & 0.19 & 0.07 & 0.06 & 0.05 \\
\hline Employed & 0.81 & 0.83 & 0.75 & 0.85 & 0.80 & 0.70 & 0.76 & 0.69 & 0.60 & 0.81 & 0.74 & 0.67 \\
\hline $\begin{array}{l}\text { Unemployed } \\
\text { Others not in }\end{array}$ & 0.02 & 0.04 & 0.04 & 0.07 & 0.08 & 0.10 & 0.05 & 0.14 & 0.13 & 0.07 & 0.11 & 0.09 \\
\hline $\begin{array}{l}\text { the labor force } \\
\text { Respondent's }\end{array}$ & 0.18 & 0.13 & 0.21 & 0.08 & 0.12 & 0.20 & 0.19 & 0.18 & 0.27 & 0.12 & 0.15 & 0.24 \\
\hline $\begin{array}{l}\text { general health } \\
\text { Respondent's } \\
\text { attitude toward }\end{array}$ & 4.46 & 4.40 & 4.40 & 4.23 & 4.19 & 4.17 & 4.23 & 4.25 & 4.39 & 3.50 & 3.42 & 3.53 \\
\hline $\begin{array}{l}\text { cohabitation } \\
\text { Respondent's }\end{array}$ & 0.74 & 0.92 & 0.88 & 0.70 & 0.93 & 0.85 & 0.80 & 0.97 & 0.93 & 0.56 & 0.79 & 0.75 \\
\hline $\begin{array}{l}\text { gender attitude } \\
\text { Ever married or }\end{array}$ & 0.82 & 0.84 & 0.78 & 0.77 & 0.78 & 0.67 & 0.66 & 0.77 & 0.68 & 0.48 & 0.50 & 0.42 \\
\hline $\begin{array}{l}\text { cohabited } \\
\text { Partner's } \\
\text { education }\end{array}$ & 0.20 & 0.27 & 0.31 & 0.24 & 0.36 & 0.56 & 0.17 & 0.31 & 0.29 & 0.19 & 0.56 & 0.49 \\
\hline Low & 0.19 & 0.24 & 0.22 & 0.14 & 0.15 & 0.12 & 0.10 & 0.11 & 0.10 & 0.02 & 0.04 & 0.02 \\
\hline Medium & 0.33 & 0.40 & 0.30 & 0.42 & 0.48 & 0.38 & 0.59 & 0.59 & 0.50 & 0.35 & 0.37 & 0.23 \\
\hline High & 0.42 & 0.28 & 0.46 & 0.43 & 0.34 & 0.42 & 0.29 & 0.22 & 0.18 & 0.43 & 0.35 & 0.44 \\
\hline $\begin{array}{l}\text { Missing/unclear } \\
\text { Partner's work } \\
\text { status }\end{array}$ & 0.07 & 0.09 & 0.02 & 0.01 & 0.02 & 0.08 & 0.02 & 0.08 & 0.22 & 0.20 & 0.24 & 0.31 \\
\hline Employed & 0.84 & 0.81 & 0.76 & 0.89 & 0.85 & 0.69 & 0.79 & 0.73 & 0.61 & 0.84 & 0.76 & 0.74 \\
\hline $\begin{array}{l}\text { Unemployed } \\
\text { Others not in }\end{array}$ & 0.02 & 0.04 & 0.04 & 0.04 & 0.07 & 0.09 & 0.05 & 0.12 & 0.06 & 0.06 & 0.09 & 0.05 \\
\hline the labor force & 0.13 & 0.15 & 0.20 & 0.07 & 0.08 & 0.22 & 0.16 & 0.15 & 0.33 & 0.10 & 0.15 & 0.22 \\
\hline $\begin{array}{l}\text { Presence of } \\
\text { minor children }\end{array}$ & 0.70 & 0.38 & 0.18 & 0.81 & 0.49 & 0.14 & 0.77 & 0.35 & 0.11 & 0.85 & 0.46 & 0.17 \\
\hline $\begin{array}{l}\text { Home ownership } \\
\text { Subjective } \\
\text { dwelling }\end{array}$ & 0.78 & 0.48 & 0.42 & 0.64 & 0.37 & 0.22 & 0.48 & 0.22 & 0.21 & 0.60 & 0.50 & 0.53 \\
\hline satisfaction & 7.57 & 7.40 & 7.44 & 7.82 & 7.37 & 7.25 & 7.99 & 7.44 & 7.56 & 5.43 & 5.08 & 5.71 \\
\hline
\end{tabular}


Tai, Baxter \& Hewitt: Do co-residence and intentions make a difference? 